\title{
Prevalence and Recurrence Rates of
}

Cytomegalovirus Infection among Patients with Hematological Diseases of the Brazilian Western Amazon

\section{Jean Melo Silva}

Universidade do Estado do Amazonas

\section{Renato Pinheiro-Silva}

Universidade do Estado do Amazonas

Regiane Costa de Oliveira

Universidade do Estado do Amazonas

Carlos Eduardo De Castro Alves

Universidade Federal do Amazonas

\section{Anderson Nogueira Barbosa}

Instituto Nacional de Pesquisas da Amazônia: Instituto Nacional de Pesquisas da Amazonia

Gemilson Pontes ( $\sim$ gemilson.pontes@inpa.gov.br)

Instituto Nacional de Pesquisas da Amazonia https://orcid.org/0000-0001-9001-7954

\section{Research Article}

Keywords: Cytomegalovirus, prevalence, epidemiology, hematological diseases, recurrent infection, Brazilian Amazon

Posted Date: February 15th, 2021

DOI: https://doi.org/10.21203/rs.3.rs-231928/v1

License: (c) (i) This work is licensed under a Creative Commons Attribution 4.0 International License. Read Full License 


\section{Abstract}

Purpose: Cytomegalovirus (CMV) is a worldwide distributed pathogen that may cause serious complications in patients with hematological diseases. This study aimed to serologically characterize the CMV infection in patients suffering from hematological diseases in Amazonas, Brazil. Methods: Serum samples from 323 patients were tested for the presence of anti-CMV IgM or IgG antibodies by an enzymelinked immunosorbent assay. Positive samples for IgM were submitted to the IgG avidity test to differentiate primary infection from recurrent infection. An epidemiological questionnaire was administered to collect sociodemographic information of the study population. Results: The overall prevalence of $\mathrm{CMV}$ infection verified in this study was $91.3 \%$. The highest rates were found in patients suffering from platelet disorders (94.5\%), anemia (93.3\%), or leukemia (91\%). The study population was predominantly composed of individuals with low socioeconomic status. Blood transfusions were more often in patients with anemia or leukemia, but it was not correlated with the positivity for CMV infection. Measurement of IgG avidity in patients positive for anti-CMV IgM demonstrated a recurrent infection rate of $5.2 \%(17 / 323)$. Over $80 \%$ of recurrent infection occurred in patients with acute lymphocytic leukemia (ALL) or anemia. Conclusions: Our findings indicated that CMV infection is highly prevalent in patients with hematological diseases from the Brazilian western Amazon. The prevalence observed progressively rose with increasing age, whereas anemia or ALL disease figured as risk factors for the recurrence of CMV infection.

\section{Introduction}

Cytomegalovirus (CMV) is a human herpesvirus endemic throughout the world [1]. Viral transmission occurs via intimate contact with infected bodily fluids and through transplacental transfer, blood transfusion, or organ transplantation [2,3].

Primary infection is usually asymptomatic in immunocompetent individuals. However, nearly $10 \%$ of infected individuals show symptoms characterized especially by the self-limiting mononucleosis-like syndrome [4,5]. In patients suffering from immunodeficiency or hematological disorders, CMV infection can cause substantial morbidity and mortality due to the virus dissemination to multiple organs as a result of uncontrolled viral replication [6,7]. In these patients, the possibility of CMV transmission through blood transfusion remains a constant concern.

CMV prevalence varies globally, with the rates reaching $100 \%$ in developing countries [8,9]. Prevalence rates of $41.9 \%, 74.4 \%$ and $50.4 \%$ have been reported in France, Croatia and the United States, respectively [10-12]. In Brazil, there are few studies regarding the epidemiology of CMV infection. Previous reports have demonstrated different prevalence rates of CMV infection in Santa Catarina (96,4\%), Rio de Janeiro $(78,7 \%)$ and São Paulo $(84,8 \%)[13,14]$. .ncreasing CMV prevalence was also associated with kidney transplants in Northern Brazil [1,15]. 
Although epidemiological studies describing CMV infection in patients with hematological diseases are scarce, elevated prevalence rates were reported in patients with thalassemia $(91 \%)$ and hematological malignancies (82\%) [16,17]. In the state of Bahia, Brazil, patients with different hematological diseases also showed elevated seroprevalence for CMV infection (89.4\%) [18]. This infection might produce a broad impact on the prognosis of these patients. Previous reports have indicated the association between $\mathrm{CMV}$ infection and the development of hematological disorders $[8,9]$. For example, cytopenia usually found in patients submitted to hematopoietic stem cell transplant is frequently linked to CMV infection [19].

The studies mentioned above demonstrate the importance of the epidemiological surveillance of CMV infection to the clinical management of patients suffering hematological diseases. Therefore, the aim of the present study was to describe the epidemiological profile of the CMV infection among patients with hematological diseases from the Brazilian western Amazon.

\section{Materials And Methods}

\section{Study Population}

From December 2016 to August 2017, we randomly recruited 323 patients from attendees at the outpatient clinic of the Hemotherapy and Hematology Hospital Foundation of Amazonas - HEMOAM. Only patients with a confirmed diagnosis for hematological diseases were eligible to participate in this study. A standardized interviewer-administered questionnaire was used to obtain information on sociodemographic and risk factors variables. Individuals of both sex and different ethnicities aged 1 to 92 years were selected. This study was approved by the Human Research Ethics Committee of the Hematology and Hemotherapy Hospital Foundation of Amazonas (approval number: 1.994.410). We ensured confidentiality to all participants, as well as the right to refuse to answer questions that could cause constraints during the study. Patients submitted to anti-viral treatment during the research period were excluded of the study to avoid any confusion bias.

\section{Infection Diagnosis}

Serum samples from the study population were tested for CMV IgM and IgG antibodies (Abs) through an enzyme-linked immunosorbent assay, performed according to the manufacturer's information (Serion ELISA classic, SerionGmbH, Germany). The optical density was measured in a spectrophotometer using a $405 \mathrm{~nm}$ filter, and the test positivity was determined according to the cut-off formula indicated by the manufacturer. To estimate the cut-off ranges, the mean value of optical densities (OD) of the positive controls was multiplied with the numerical data from the quality control certificate $(O D=0.600 \times$ positive control mean for upper cut-off; $O D=0.350 \times$ positive control mean for lower cut-off).

To differentiate primary infection from recurrent infection, serum samples from patients who were positive for IgM were submitted to the IgG avidity test. For this assay, the same commercial kit and protocol were used. However, one elution step was added with an $8 \mathrm{M}$ urea solution as agent antigen 
binding of low avidity. The tests were performed in duplicate, and the samples were tested with the addition of $8 \mathrm{M}$ urea and without urea. The avidity index was calculated by the ratio of the samples Optical Density (OD) values that were treated with $8 \mathrm{M}$ urea by the samples OD values that were untreated with urea, multiplied by $100(\operatorname{lgG}+8 \mathrm{M}$ urea/lgG $\times 100)$. Avidity index $<45 \%$ was considered as indicative of recent infection and $>65 \%$ as recurrent infection.

\section{Statistical Analysis}

Descriptive statistical analysis was used to evaluate the sociodemographic variables by calculating measures of central tendency and dispersion. The results were categorized according to normality. The Odds Ratio (OR) analysis was employed to assess the association between socio-demographic factors and the type of hematological disease with susceptibility to CMV infection. OR values were estimated from log-binomial models. One way ANOVA was used to compare the serum levels of CMV antibodies among the study population. The F-test was applied to evaluate the variances of the serum antibody levels. All statistical analyses were performed using Graphpad Prism v.5.0 and Biostat v.5.0. A value of $p$ $<0.05$ was considered significant.

\section{Results}

\section{Prevalence of CMV Infection According to Hematological Disease and Blood Transfusion Rates}

The presence of CMV IgG Abs was detected in 295 patients (91.3\%) (Table 1). From this number, 179 underwent 2 or more blood transfusion during a one-year period. However, the association between transfusion and prevalence rates was not statically significant $(p=0.36)$.

The prevalence of CMV infection according to the hematological diseases and blood transfusions rates (one-year period) observed in this study are shown in Figure 1. Leukemia was the most prevalent hematological disease in the study population. Patients with leukemia showed CMV prevalence and blood transfusion rates of $93.3 \%$ and $77.77 \%$, respectively. Anemia (different etiologies) was the second most frequent disease (Figure 1). A total of 37 patients $(50.68 \%$ ) was carrier of severe anemia. These patients were often submitted to multiple blood transfusions per year.

Patients with lymphoma and immune thrombocytopenic purpura (ITP) exhibited CMV prevalence of $91.7 \%$ and $94 \%$, respectively (Table 2 ). Individuals with sickle cell anemia had the highest blood transfusion frequency (82.35\%) and exhibited a CMV prevalence of $94.11 \%$.

\section{CMV prevalence According to Sociodemographic Characteristics of Study Population}

Most of the patients declared themselves as brown (65.3\%) and single (70.5\%). The average age of the study population was 26 years (Table 3). The prevalence of CMV infection observed among brown and black patients was $92.3 \%$ and $91.3 \%$, respectively, whereas in white patients the CMV prevalence was $89.9 \%$. No statistically significant association was observed between seropositivity for CMV infection and ethnicity or marital status. 
The study population was comprised of individuals with low education and purchasing power levels. The majority of patients was from families earning a minimum (50.4\%) or two to five minimum wages (44.9\%). Individuals with middle-level education (26.1\%), complete high school (22\%), or elementary school $(20.7 \%)$ were more frequent in the study population. Individuals in the elementary education showed decreased susceptibility to CMV infection $(p=0.0002)$. The association between CMV infection and occupation of student was also statistically significant $(p=0.005)$, suggesting also that students are less susceptible to CMV infection. No correlation was observed between condom usage and positivity for CMV infection. An overwhelming number of patients did not know about CMV infection (94\%), especially regarding transmission and prevention (Table 3).

\section{Serological Profile of the Study Population}

Hemophilic patients presented higher CMV IgG serum levels (OD. Mean $=1.842$ ) when compared to the other groups of patients (Supplementary Figure 1A). Sex-based analysis showed similar prevalence rates $(p=0.750)$ between women $(92.1 \%)$ and men (90.5\%) (Supplementary figure 1B). However, when the results were stratified according to age, prevalence rates gradually rose with increasing age (Figure 2). Furthermore, our findings demonstrated that patients aged $1-10$ or 11-19 years exhibited lower levels of serum CMV IgG (mean OD = 1.494 and 1.562, respectively). In contrast, patients aged 20-29 years old displayed the highest levels (mean OD $=1.774$ ) The difference in serum CMV IgG levels observed between the age groups 1-10 and 20-29 was statistically significant $(p=0.02)$ (Figure 2 ).

The occurrence of active $\mathrm{CMV}$ infection was assessed trough the detection of serum IgM Ab. A positivity of 5.3\% (17/323) for CMV IgM Ab (Table 4) was observed among the study population. CMV-IgM positive patients were carriers of anemia of different etiologies $(n=7), \operatorname{ALL}(n=7)$, lymphoma $(n=2)$ and thrombocytopenia $(n=1)$ (Table 3). Patients with anemia presented the higher IgM levels (O.D. mean = 0.763). The CMV IgM Abs serum levels variance verified between patients with anemia and ALL was statistically significant $(p=0.01)$ (Figure $3 A$ ). No statistical significance was verified between IgM Abs positivity and $\operatorname{sex}(p=0.45)$ (Figure $3 \mathrm{~B})$.

The IgG avidity test revealed that all CMV active infection resulted from a recurrence of the infection, since the individuals showed an avidity index higher than $60 \%$ (Figure 4).

\section{Discussion}

Despite the CMV infection is widespread all over the world, the epidemiological surveillance of this virus is still neglected [20]. Raising awareness of CMV dissemination in Brazil is imperative to combat the infection and to the clinical management of patients, especially patients with hematological diseases.

Our findings demonstrated that the CMV infection is highly prevalent among patients with hematological diseases from the Brazilian western Amazon. The study population showed a prevalence rate (91\%)higher than the one observed (67.6\%) in the city of Manaus [21]. Likewise, a study carried out in the Hemotherapy and Hematology Foundation of the State of Bahia (HEMOBA), in Brazil, verified an 
increased prevalence rate of CMV infection (89.4\%) in patients with different hematological diseases [2]. Preeminent seropositivity for CMV infection were also observed in patients with thalassemia $(94.1 \%)$ from Iran and patients with idiopathic thrombocytopenic purpura (86.4\%) from China [22]. Our results reveal a wide CMV circulation in the study population. The present study is a pioneer in describing the epidemiology of CMV infection in patients suffering from hematological diseases in the Brazilian western Amazon.

CMV infection tends to be more frequent in women than in men. This situation probably happens due to the greater susceptibility of women to sexual transmission and because women generally spend more time taking care of children (working in daycare centers or at home), as suggested by some studies [6,23]. Indeed, the risk of primary CMV infection is increased in women of childbearing age $[10,24]$. In this study, we did not find any correlation between sexes and susceptibility to CMV infection. Similarly, no difference in prevalence rates was observed in white and non-white individuals, even though the positivity for CMV infection has been found $30 \%$ higher in non-white people earlier [23]. Our findings also demonstrated that elementary education and the occupation student was directly associated with the low susceptibility to CMV infection. However, the low level of education, inadequate sanitary conditions, cultural aspects, and families with a great number of individuals were already described as the main factors behind the elevated CVM prevalence rates [12,23,25]. Similarly, previous findings showed CMV prevalence ranging from $75 \%$ to $97.7 \%$ among university students from Middle West [26,27].Nevertheless, the majority of students of the study population were very young, which may explain the low susceptibility to CMV infection verified in these groups once the prevalence rates were more prominent among older people.

Sexual transmission of CMV may be facilitated by viral persistence in the female genital tract, representing an important way of transmission in sexually active adults and adolescents[28]. In developed countries, CMV infection frequently happens in two moments: during the first 2-3 years of life or between adolescence and adulthood (16 to 30 years)[29]. In the present study, nearly half of the patients (43.7\%) declared no condom usage during sexual intercourse, but we did not find any correlation between this factor and the susceptibility for CMV infection.

Our results demonstrated that the prevalence of CMV infection was greater in patients with anemia of different etiologies (93.3\%), platelet diseases (94.9\%), lymphoma (91.7\%), and leukemia (91\%). Increased prevalence of CMV infection has been previously described in patients with aplastic anemia, lymphoma, or leukemia [30-32]. In some cases, the development of these diseases and the morbimortality of patients were related to CMV infection [30,32,33]. Epidemiological studies showing CMV infection prevalence in patients with platelet disease are scarce, but the correlation between the development of thrombocytopenia and CMV infection was also reported. Although this is not a typical situation, CMV infection may lead to thrombocytopenia or thrombocytopenic purpura in healthy children during the neonatal period [34]. In the present study, we did not analyze the association between CMV infection and the development of these diseases, nor its connection with the enhancement of patients' morbimortality. However, the epidemiological surveillance of CMV infection in patients with hematological diseases provided by this study may be an important tool to improve their clinical management. 
Detection of serum CMV IgM Abs may indicate a recent infection or a recurrent infection ( reactivation/reinfection) [35-37]. Elevated IgM and low IgG Abs titers suggest primary infection rather than reactivation or reinfection [38]. All 17 active infections observed in our study resulted from recurrent infection since the patients presented high avidity CMV IgG. Positivity rates for CMV IgM Abs vary according to population, culture and region. A study carried out with women in reproductive age from the United States verified $2.9 \%$ of positivity for CMV IgM Abs [38]. Pregnant women from Ireland showed $5.9 \%$ of positivity for CMV IgM Abs, whereas among patients undergoing hemodialysis from Croatia the rate observed was $2.3 \%[39,40]$. In Brazil, $1.9 \%$ of blood donors from the Southern region showed CMV IgM positivity [13]. The present study found a seropositivity of 5.3\% for CMV IgM Abs in the study population, which is higher than most of the rates described elsewhere. These findings suggest that the hematological diseases may influence the recurrence of CMV infection.

In the context of the hematological diseases, recurrent CMV infection has been typically associated with the immunosuppression caused by therapeutic schemes. Patients suffering from chronic lymphocytic leukemia showed a CMV reactivation rate of $66 \%$ after alemtuzumab therapy [38]. Furthermore, an elevated proportion of CMV reactivation (84.6\%) was observed in children with hemoglobinopathies submitted to hematopoietic stem cell transplantation and alemtuzumab treatment [42]. In the present study, we did not assess the clinical records of the study population to search for possible links between treatment and the recurrence of CMV infection.

Most patients positive for CMV IgM Abs suffered from ALL or anemia (various etiologies). CMV reactivation is considered elevated individuals with Leukemia. Increased rates of CMV reactivation were equally noted in patients with leukemia from India (11.3\%) and Iraq (12\%) [43,44]. Another study observed CMV reactivation in $66 \%$ of patients with chronic lymphocytic leukemia, after alemtuzumab therapy [41]. These studies indicate that leukemia increases the risk of CMV recurrent infection by unknown mechanisms. However, it has been recognized that the Natural Killer (NK) cells are the key factor to combat CMV infection [45]. Indeed, NK cell abnormality or deficiency is a risk factor for CMV reactivation [46]. This condition could explain the occurrence of elevated CMV reactivation among patients with ALL described in this study and elsewhere, once NK cell abnormalities were already reported in these patients [47]. In this study, we did not assess the phenotype of NK cells in patients positive for CMV IgM to verify this correlation. Yet, our findings raise the following questions: Would the patients with ALL or anemia be more prone to $\mathrm{CMV}$ recurrence? Are the recurrence rates associated with immunological suppression condition inflicted by ALL or Anemia diseases? A longitudinal study with a larger sample size must be done to answer this question.

In the present study, we assessed the serum levels of CMV IgG Abs according to age. The lowest serum levels were observed among children aged 1-10 years, whereas patients aged 20-29 years showed the highest IgG serum levels. A study conducted in the United States with 6.067 women aged 12-49 years demonstrated that serum levels of both IgM and IgG anti-CMV increased gradually with age progression [38]. This correlation was equally observed in a study carried out with 3.304 individuals from Portugal [48]. The presence of high serum levels of anti-CMV IgG antibodies has also been linked to the 
progression of HIV disease in patients from Uganda, Africa [49]. Also, the clinical course of CMV infection in patients submitted to kidney transplants was associated with anti-CMV antibody titers [50]. At present, no correlation between serum levels of anti-CMV antibodies and hematologic disease progression has been identified.

Although the present study found no significant difference in anti-CMV Ab serum levels when it was analyzed according to the hematological diseases, these serum levels may be used as an indicator of immunocompetence status in the context of hematologic disease. Also, CMV infection could be a key factor linked to patient morbidity. Thus these findings bring new insights not only regarding the epidemiological profile of CMV infection in the study population but also concerning the influence of the hematological disease on the infection recurrence and vice-versa. Therefore, the data presented here may be a starting point for new studies, especially the ones that try to elucidate the negative prognostic impact of CMV infection in patients with hematological disease.

\section{Declarations}

Funding: This study was financed in part by the Coordenação de Aperfeiçoamento de Pessoal de Nível Superior- Brasil (CAPES)- Finance code PROCAD AMAZÔNIA 88881.200581/201801.

Acknowledgments: The authors gratefully acknowledge the Fundação de Hematologia e Hemoterapia do Amazonas for all support provided during this study.

Data availability: All data generated or analysed during this study areincluded in this published article and its supplementary information files.

Code availability: Not applicable

Conflicts of Interest: The authors declare no conflict of interest.

Ethical approval: This study was approved by the Human Research Ethics Committee of the Hematology and Hemotherapy Hospital Foundation of Amazonas (approval number: 1.994.410).

Informed consent: All the patients include in this study signed a written consent form.

\section{References}

1. Voevodin AF, Marx PA. Cytomegaloviruses. In: Simian Virology. 2009. p. 309-22.doi: 10.1002/9780813809793.ch14

2. Matos BS, Meyer R, Lima F. cytomegalovirus infection among patients with hematologic disorders in Bahia State, Brazil. J. Med. Virol. 2011;83:298-304. doi: 10.1002/jmv

3. Lanzieri TM, Kruszon-Moran D, Amin MM, Bialek SR, Cannon MJ, Carroll MD, et al. Seroprevalence of Cytomegalovirus among Children 1 to 5 Years of Age in the United States from the National Health 
and Nutrition Examination Survey of 2011 to 2012. Clin. Vaccine Immunol. 2015;22:245-7. doi: 10.1128/cvi.00697-14

4. Lancini D, Faddy HM, Flower R, Hogan C. Cytomegalovirus disease in immunocompetent adults. Med. J. Aust. 2014;201:578-80. doi: 10.5694/mja14.00183

5. Sarma S, Little DHW, Ali T, Jones E, Haider S. Cytomegalovirus Primary Infection in an Immunocompetent Female with Mononucleosis Features: A Review of Mononucleosis-Like Syndromes. Can. J. Gen. Intern. Med. 2018;13:39-43. doi: 10.22374/cjgim.v13i3.258

6. Junqueira JMJ, Sancho TM, dos Santos VA. Citomegalovírus: revisão dos aspectos epidemiológicos, clínicos, diagnósticos e de tratamento. Rev Saúde.com 2008;7:44-57.

7. Tomtishen J. Human cytomegalovirus tegument proteins (pp65, pp71, pp150, pp28). Virol. J. 2012;9:22. doi: 10.1186/1743-422X-9-22

8. Nguyen Q, Estey E, Raad I, Rolston K, Kantarjian H, Jacobson K, et al. Cytomegalovirus pneumonia in adults with leukemia: an emerging problem. Clin. Infect. Dis. 2001;32:539-45. doi: 10.1086/318721

9. Chemaly RF, Torres HA, Hachem RY, Nogueras GM, Aguilera EA, Younes A, et al. Cytomegalovirus pneumonia in patients with lymphoma. Cancer 2005;104:1213-20. doi: 10.1002/cncr.21294

10. Antona D, Lepoutre A, Fonteneau L, Baudon C, Halftermeyer-Zhou F, Le Strat Y, et al. Seroprevalence of cytomegalovirus infection in France in 2010. Epidemiol. Infect. 2017; doi:

$10.1017 /$ S0950268817000103

11. Vilibic-Cavlek T, Kolaric B, Beader N, Vrtar I, Tabain I, Mlinaric-Galinovic G. Seroepidemiology of cytomegalovirus infections in Croatia. Wien. Klin. Wochenschr. 2017;129:129-35. doi: 10.1007/s00508-016-1069-7

12. Bate SL, Dollard SC, Cannon MJ. Cytomegalovirus Seroprevalence in the United States: The National Health and Nutrition Examination Surveys, 1988-2004. Clin. Infect. Dis. 2010;50:1439-47. doi: $10.1086 / 652438$

13. Souza MA, Passos AM, Treitinger A, Spada C. Seroprevalence of cytomegalovirus antibodies in blood donors in southern, Brazil. Rev. Soc. Bras. Med. Trop. 2011;43:359-61. doi: 10.1590/s003786822010000400004

14. Serra FC, Machado J, Nicola MH, Claudia M, Jorge a S, Eduardo L, et al. Soroprevalência De Citomegalovírus Em Gestantes Brasileiras De Classe Socioeconômica Favorecida. J bras Doenças Sex Transm 2009;21:12-5.

15. Silva DFL, Gomes RHS, Moraes MM, Medeiros RFL, Santos ECO Jl. perfil sorológico e molecular da infecção pelo citomegalovírus em pacientes transplantados de Belém-PA. Earth Sci. China Univ. Geosci. 2007;15:369-78. doi: 10.3799/dqkx.2016.023

16. Piukovics K, Terhes G, Gurbity-Pálfi T, Bereczki Á, Rárosi F, Deák J, et al. Cytomegalovirus infection in patients with haematological diseases and after autologous stem cell transplantation as consolidation: a single-centre study. Ann. Hematol. 2017;96:125-31. doi: 10.1007/s00277-016-28317 
17. Moghimi M, Doosti M, Vahedian-Ardakani HA, Talebi A, Akhavan-Ghalibaf M, Najafi A, et al. Serological Study on Cytomegalovirus and Toxoplasma Gondii in Thalassemia Major Patients of Yazd, Iran. Iran. J. Pediatr. Hematol. Oncol. 2015;5:149-14954.

18. De Matos SB, Meyer R, Lima FW de M. Seroprevalence and serum profile of cytomegalovirus infection among patients with hematologic disorders in Bahia State, Brazil. J. Med. Virol. 2011;83:298-304. doi: 10.1002/jmv.21965

19. Cho SY, Lee DG, Kim HJ. Cytomegalovirus infections after hematopoietic stem cell transplantation: Current status and future immunotherapy. Int. J. Mol. Sci. 2019;20:2666. doi: 10.3390/ijms20112666

20. Cannon MJ, Schmid DS, Hyde TB. Review of Cytoimegalovirus seroprevalence and demographic characteristics associated with infection. Rev. Med. Virol. 2010;20:202-13. doi: 10.1002/rmv

21. Tiguman GMB, Poll LB, de Castro Alves CE, Pontes GS, Silva MT, Galvao TF. Seroprevalence of cytomegalovirus and its coinfection with epstein-barr virus in adult residents from manaus: $A$ population-based study. Rev. Soc. Bras. Med. Trop. 2020;53:e20190363. doi: 10.1590/0037-86820363-2019

22. Ding Y, Zhao L, Mei H, Zhang SL, Huang ZH. Role of myeloid human cytomegalovirus infection in children's idiopathic thrombocytopenic purpura. Pediatr. Hematol. Oncol. 2007;24:179-88. doi: $10.1080 / 08880010601166421$

23. Cannon MJ, Schmid SD, Hyde TB. Review of cytomegalovirus seroprevalence and demographic characteristics associated with infection. Rev. Med. Virol. 2010;20:202-13. doi: 10.1002/rmv

24. Lachmann R, Loenenbach A, Waterboer T, Brenner N, Pawlita M, Michel A, et al. Cytomegalovirus (CMV) seroprevalence in the adult population of Germany. PLoS One 2018;13:e0200267. doi: 10.1371/journal.pone.0200267

25. Ahmed SA, Al-Joudi FS, Zaidah AW, Roshan TM, Rapiaah M, Abdullah YMS, et al. The prevalence of human cytomegalovirus seropositivity among blood donors at the unit of blood transfusion medicine, Hospital Universiti Sains Malaysia. Southeast Asian J. Trop. Med. Public Health 2006;294-6.

26. Khudir MK, Molan A-L. Seroprevalence of cytomegalovirus among healthy students at Diyala University, Diyala, Iraq. IOSR J. Pharm. Biol. Sci. 2014;9:59-61. doi: 10.9790/3008-09155961

27. Barah F. Prevalence of herpes simplex types 1 and 2, varicella zoster virus, cytomegalovirus, and immunoglobulin $\mathrm{G}$ antibodies among female university students in Syria. Saudi Med. J. 2012;33:990-4.

28. Forman MS, Vaidya D, Bolorunduro O, Diener-West M, Pass RF, Arav-Boger R. Cytomegalovirus Kinetics Following Primary Infection in Healthy Women. J. Infect. Dis. 2017;215:1523-6. doi: 10.1093/infdis/jix188

29. Blut A. Human Cytomegalovirus (HCMV)-Revised. Transfus. Med. Hemotherapy 2010;37:365-75. doi: $10.1159 / 000322141$

30. Ho SY. To the Editor: Letter to the Editor. Increased prevalence of CMV gB3 in marrow of patients with aplastic anemia. J. Cardiovasc. Electrophysiol. 2010;21:891-2. doi: 10.1111/j.1540- 
8167.2010.01724.x

31. Handous I, Achour B, Marzouk M, Rouis S, Hazgui O, Brini I, et al. Co-infections of human herpesviruses (CMV, HHV-6, HHV-7 and EBV) in non-transplant acute leukemia patients undergoing chemotherapy. Virol. J. 2020;17:1-15. doi: 10.1186/s12985-020-01302-4

32. Torres HA, Kontoyiannis DP, Aguilera EA, Younes A, Luna MA, Tarrand JJ, et al. Cytomegalovirus infection in patients with lymphoma: An important cause of morbidity and mortality. Clin. Lymphoma Myeloma [Internet] 2006;6:393-8. doi: http://dx.doi.org/10.3816/CLM.2006.n.016doi: 10.3816/CLM.2006.n.016

33. Guven GS, Uzun O, Cakir B, Akova M, Unal S. Infectious complications in patients with hematological malignancies consulted by the Infectious Diseases team: A retrospective cohort study (1997-2001). Support. Care Cancer 2006;14:52-5. doi: 10.1007/s00520-005-0836-1

34. Jin MJ, Kim Y, Choi EM, Shim YJ, Kim HS, Suh JK, et al. Clinical characteristics and treatment courses for cytomegalovirus-associated thrombocytopenia in immunocompetent children after neonatal period. Blood Res. 2018;53:110-6. doi: 10.5045/br.2018.53.2.110

35. Carlson A, Norwitz ER, Stiller RJ. Cytomegalovirus infection in pregnancy: should all women be screened? Rev. Obstet. Gynecol. 2010;3:172-9. doi: 10.3909/riog0131

36. Duff P. A thoughtful algorithm for the accurate diagnosis of primary CMV infection in pregnancy. Am. J. Obstet. Gynecol. 2007;193:196-7. doi: 10.1016/j.ajog.2006.09.020

37. Benoist G, Leruez-Ville M, Magny JF, Jacquemard F, Salomon LJ, Ville Y. Management of pregnancies with confirmed cytomegalovirus fetal infection. Fetal Diagn. Ther. 2013;33:203-14. doi: $10.1159 / 000342752$

38. Dollard SC, Staras SAS, Amin MM, Schmid DS, Cannon MJ. National Prevalence Estimates for Cytomegalovirus IgM and IgG Avidity and Association between High IgM Antibody Titer and Low IgG Avidity. Clin. Vaccine Immunol. 2011;18:1895-9. doi: 10.1128/cvi.05228-11

39. Vilibic-Cavlek T, Kolaric B, Ljubin-Sternak S, Kos M, Kaic B, Mlinaric-Galinovic G. Prevalence and dynamics of cytomegalovirus infection among patients undergoing chronic hemodialysis. Indian J. Nephrol. 2015;25:95-8. doi: 10.4103/0971-4065.139488

40. R.J. D, P. S, H. A, E. H, W. F, C. DG, et al. Pregnancy outcomes of mothers with detectable CMV-specific IgM antibodies: A three-year review in a large irish tertiary referral maternity hospital. Infect. Dis. Obstet. Gynecol. 2015;2015:218080. doi: http://dx.doi.org/10.1155/2015/218080

41. Laurenti L, Piccioni P, Cattani P, Cingolani A, Efremov D, Chiusolo P, et al. Cytomegalovirus reactivation during alemtuzumab therapy for chronic lymphocytic leukemia: Incidence and treatment with oral ganciclovir. Haematologica 2004;89:1248-52.

42. Elgarten CW, Myers RM, Levy E, Freedman JL, Bunin NJ, Fisher BT, et al. Cytomegalovirus Reactivation in Children with Hemoglobinopathies Who Undergo Hematopoietic Cell Transplantation with Distal Alemtuzumab. Biol. Blood Marrow Transplant. 2019;25:S309-10. doi: 10.1016/j.bbmt.2018.12.650 
43. Gulia S, Sengar M, Dangi U, Menon H, Biswas S, Kelkar R, et al. Prevalence and patterns of cytomegalovirus (CMV) reactivation in adult acute lymphoblastic leukemia patients on chemotherapy: Single center experience. Blood 2011;118:2583.

44. Omer AR, Salih JI, Al-Nakshabandi AA. Frequency of blood-borne viral infections among leukemic patients in central Iraq. Saudi Med. J. 2011;32:55-61.

45. Kuijpers TW, Baars PA, Dantin C, Van Den Burg M, Van Lier RAW, Roosnek E. Human NK cells can control CMV infection in the absence of T cells. Blood 2008;914-5. doi: 10.1182/blood-2008-05157354

46. Von Müller L, Klemm A, Durmus N, Weiss M, Suger-Wiedeck H, Schneider M, et al. Cellular immunity and active human cytomegalovirus infection in patients with septic shock. J. Infect. Dis. 2007;196:1288-95. doi: 10.1086/522429

47. Valenzuela-Vazquez L, Núñez-Enríquez JC, Sánchez-Herrera J, Jiménez-Hernández E, Martín-Trejo JA, Espinoza-Hernández LE, et al. Functional characterization of NK cells in Mexican pediatric patients with acute lymphoblastic leukemia: Report from the Mexican Interinstitutional Group for the Identification of the Causes of Childhood Leukemia. PLoS One 2020;15:e0227314. doi: 10.1371/journal.pone.0227314

48. Lopo S, Vinagre E, Palminha P, Paixão MT, Nogueira P, Freitas MG. Seroprevalence to cytomegalovirus in the portuguese population, 2002-2003. Eurosurveillance 2011;16:19896.

49. Patel EU, Gianella S, Newell K, Tobian AAR, Kirkpatrick AR, Nalugoda F, et al. Elevated cytomegalovirus IgG antibody levels are associated with HIV-1 disease progression and immune activation. AIDS 2017;31:807-13. doi: 10.1097/QAD.0000000000001412

50. Iglesias-Escudero M, Moro-García MA, Marcos-Fernández R, García-Torre A, Álvarez-Argüelles ME, Suárez-Fernández ML, et al. Levels of anti-CMV antibodies are modulated by the frequency and intensity of virus reactivations in kidney transplant patients. PLoS One 2018;13:e0194789. doi: 10.1371/journal.pone.0194789

\section{Tables}

Table 1. Prevalence of CMV infection in patients with hematological diseases.

\begin{tabular}{ccccc}
\hline CMV IgG & N (\%) & Transfusion Rates *(\%) & OD (95\% CI) & $p$-value \\
\hline Seropositive & $295(91.3)$ & $179(60.66 \%) * *$ & $0.8573(0.3823-1.922)$ & 0.360 \\
Seronegative & $28(8.7)$ & $18(72 \%) * * *$ & & \\
\hline Total & 323 & $197(61 \%)$ & & \\
\hline
\end{tabular}

OR = Odds Ratio; CI = Confidence Interval. * number of patients submitted to 2 or more transfusion during a one-year period; ** percentage taking account the total number of seropositive individuals; $* * *$ percentage taking account the total number of seronegative individuals. 
Table 2. Prevalence rates of CMV infection according to the hematological disease.

\begin{tabular}{|c|c|c|c|c|c|}
\hline Hematological Diseases & $\mathbf{N}$ & $\begin{array}{c}\text { Positive } \\
\text { N (\%) }\end{array}$ & $\begin{array}{c}\text { Negative } \\
\text { N (\%) }\end{array}$ & OR $(95 \% \mathrm{CI})$ & $p$-value \\
\hline Anemia & 90 & $84(93,3)$ & $6(6,7)$ & $1.45(0.57-3.72)$ & 0.565 \\
\hline \multicolumn{6}{|c|}{ (Aplastic, Sickle cell, Hemolytic and others) } \\
\hline Platelets diseases & 39 & $37(94,9)$ & $2(5,1)$ & $1.86(0.42-8.18)$ & 0.592 \\
\hline Spherocytosis & 2 & - & $2(100)$ & - & \\
\hline Hemophilia & 9 & $9(100)$ & - & - & \\
\hline Hemoglobinopathies & 3 & $3(100)$ & - & - & \\
\hline Leukemia & 144 & $131(91,0)$ & $13(9,0)$ & $0.92(0.42-2.00)$ & 0.994 \\
\hline AML & 24 & $23(95,8)$ & $1(4,2)$ & - & \\
\hline CML & 14 & $13(93)$ & $1(7)$ & - & \\
\hline ALL & 100 & $91(91)$ & $9(9)$ & - & \\
\hline CLL & 3 & $3(100)$ & - & - & \\
\hline ATL & 2 & $2(100)$ & - & - & \\
\hline Lymphoma & 24 & $22(91,7)$ & $2(8,3)$ & $1.04(0.23-4.70)$ & 0.751 \\
\hline Multiple myeloma & 4 & $3(75)$ & $1(25)$ & - & \\
\hline Polycythemia & 1 & - & $1(100)$ & - & \\
\hline Myelodysplastic Syndrome & 3 & $3(100)$ & - & - & \\
\hline Thalassemia & 4 & $3(75)$ & $1(25)$ & - & \\
\hline
\end{tabular}

ALL = Acute Lymphocytic Leukemia; AML = Acute Myeloid leukemia; CLL = Chronic Lymphocytic Leukemia; $\mathrm{CML}=$ Chronic Myeloid Leukemia; ATL = Adult T-cell Leukemia/Lymphoma; OR = Odds Ratio; CI = Confidence Interval.

Table 3. CMV infection prevalence according to sociodemographic characteristics of the study population. 


\begin{tabular}{|c|c|c|c|c|c|c|}
\hline $\begin{array}{c}\text { Sociodemographic } \\
\text { Characteristics }\end{array}$ & N (\%) & $\begin{array}{l}\text { Age } \\
\text { range }\end{array}$ & $\begin{array}{c}\text { CMV-positive } \\
\text { N (\%) }\end{array}$ & $\begin{array}{c}\text { CMV-negative } \\
\text { N (\%) }\end{array}$ & $\begin{array}{c}\text { OR } \\
(95 \% \mathrm{CI})\end{array}$ & $p$-value \\
\hline \multicolumn{7}{|l|}{ Ethnicity } \\
\hline Black & $23(7.1)$ & $2-53$ & $21(91.3)$ & $2(8.7)$ & 1.00 & \\
\hline White & $89(27.6)$ & $1-92$ & 80 (89.9) & $9(10.1)$ & $0.79(0.34-1.81)$ & 0.728 \\
\hline Brown & $211(65.3)$ & $1-90$ & $194(91.9)$ & $17(8.1)$ & $1.24(0.56-2.75)$ & 0.742 \\
\hline \multicolumn{7}{|l|}{ Family income } \\
\hline 1 minimum wage & $163(50.5)$ & $1-90$ & $149(91.4)$ & $14(8.6)$ & $1.02(0.47-2.22)$ & 0.884 \\
\hline 2 to 5 minimum wages & $145(44.9)$ & $1-92$ & $132(91.0)$ & $13(9.0)$ & $0.93(0.43-2.03)$ & 0.978 \\
\hline 6 to 9 minimum wages & $13(4.0)$ & $7-67$ & $12(92.3)$ & $1(7.7)$ & 1.00 & \\
\hline More than 10 minimum wages & $2(0.6)$ & $48-55$ & $2(100.0)$ & & & \\
\hline \multicolumn{7}{|l|}{ Level of schooling } \\
\hline Illiterate* & $23(7.3)$ & $1-92$ & $22(95.7)$ & $1(4.3)$ & $2.13(0.27-16.50)$ & 0.729 \\
\hline Literate** & $29(9.2)$ & $4-90$ & $27(93.1)$ & $2(6.9)$ & $1.27(0.28-5.72)$ & 0.972 \\
\hline Elementary school & $38(12.1)$ & $6-15$ & $28(73.7)$ & $10(26.3)$ & $0.17(0.07-0.42)$ & $<0.0001$ \\
\hline Incomplete middle school & $7(2.2)$ & $12-14$ & $6(85.7)$ & $1(14.3)$ & $0.54(0.06-4.71)$ & 0.900 \\
\hline Complete middle school & $82(26.1)$ & $7-78$ & 77 (93.9) & $5(6.1)$ & 1.00 & \\
\hline Incomplete high school & $1(0.3)$ & 16 & $1(100.0)$ & & & \\
\hline Complete high school & $69(22.0)$ & $16-77$ & $66(95.7)$ & $3(4.3)$ & $2.38(0.69-8.24)$ & 0.246 \\
\hline Undergraduate & $35(11.1)$ & $19-67$ & $33(94.3)$ & $2(5.7)$ & $1.60(0.36-7.12)$ & 0.766 \\
\hline Not Informed & $30(9.6)$ & $3-90$ & $27(90.0)$ & $3(10.0)$ & & \\
\hline \multicolumn{7}{|l|}{ Occupation } \\
\hline Student & $94(48.2)$ & $5-33$ & $79(84.0)$ & $15(16.0)$ & $0.11(0.03-0.51)$ & 0.002 \\
\hline Housewife & $41(21.0)$ & $22-90$ & $39(95.1)$ & $2(4.9)$ & 1.00 & \\
\hline Retired & $17(8.7)$ & $50-92$ & $17(100.0)$ & & & \\
\hline Unemployed & $37(19.0)$ & $16-87$ & $37(100.0)$ & & & \\
\hline Not Informed & $6(3.1)$ & $20-28$ & $6(100.0)$ & & & \\
\hline \multicolumn{7}{|l|}{ Condom usage } \\
\hline Always & $61(30.8)$ & $16-60$ & $58(95.1)$ & $3(4.9)$ & 1.00 & \\
\hline Intermittent & $15(7.6)$ & $17-64$ & $15(100.0)$ & & & \\
\hline Never & $111(56.1)$ & $16-90$ & $105(94.6)$ & $6(5.4)$ & $0.72(0.17-2.97)$ & 0.913 \\
\hline Not Informed & $11(5.6)$ & $16-90$ & $11(100.0)$ & & & \\
\hline \multicolumn{7}{|l|}{ Awareness of CMV infection } \\
\hline None & $304(94.1)$ & $1-92$ & $276(90.8)$ & $28(9.2)$ & & \\
\hline Little & $17(5.3)$ & $5-56$ & $17(100.0)$ & & & \\
\hline Not Informed & $2(0.6)$ & $17-39$ & $2(100.0)$ & & & \\
\hline
\end{tabular}

OR = Odds Ratio; $\mathrm{CI}=$ Confidence Interval. $*$ people able to writing and reading. ${ }^{* *}$ people unable to read and write. All individuals in both groups literate and illiterate were not attending school.

Table 4. Characteristics of patients positive for CMV IgM Abs. 


\begin{tabular}{|c|c|c|c|c|c|c|c|}
\hline Hematological Diseases & $\mathbf{N}$ & $\begin{array}{l}\text { Sex } \\
\text { (n) }\end{array}$ & $\begin{array}{c}\text { Age } \\
\text { (media) }\end{array}$ & $\begin{array}{l}\text { Occupation } \\
\text { (n) }\end{array}$ & $\begin{array}{c}\text { Transfusion } \\
* \\
\text { (n) }\end{array}$ & $\begin{array}{c}\text { OR } \\
(95 \% \text { IC) }\end{array}$ & $p$-value \\
\hline $\begin{array}{l}\text { Anemia of different } \\
\text { etiologies }\end{array}$ & 7 & $\begin{array}{c}\mathrm{F}(6) \\
\mathrm{M} \\
(1)\end{array}$ & 46 & $\begin{array}{c}\text { Retired (1) } \\
\text { Autonomous (1) } \\
\text { Housewife (3) } \\
\text { Student (2) }\end{array}$ & $\begin{array}{l}\text { Yes (3) } \\
\text { No (4) }\end{array}$ & $\begin{array}{l}(0.69- \\
5.10)\end{array}$ & 0.327 \\
\hline ALL & 7 & $\begin{array}{c}F(2) \\
M \\
(5)\end{array}$ & 29 & $\begin{array}{l}\text { Housewife (2) } \\
\text { Unemployed (5) }\end{array}$ & $\begin{array}{l}\text { Yes (5) } \\
\text { No (2) }\end{array}$ & $\begin{array}{l}(0.32- \\
2.32)\end{array}$ & 0.968 \\
\hline Burkitt's lymphoma & 1 & M & 5 & Unemployed & Yes & & \\
\hline Non-Hodgkin's lymphoma & 1 & M & 45 & $\begin{array}{c}\text { Hemotherapy } \\
\text { technician }\end{array}$ & No & & \\
\hline Thrombocytopenia & 1 & $\mathrm{~F}$ & 52 & House wife & No & & \\
\hline
\end{tabular}

$\mathrm{OR}=$ Odds Ratio; $\mathrm{CI}=$ Confidence Interval. $\mathrm{F}=$ Female; $\mathrm{M}=$ Male

\section{Figures}


CMV prevalence transfusion

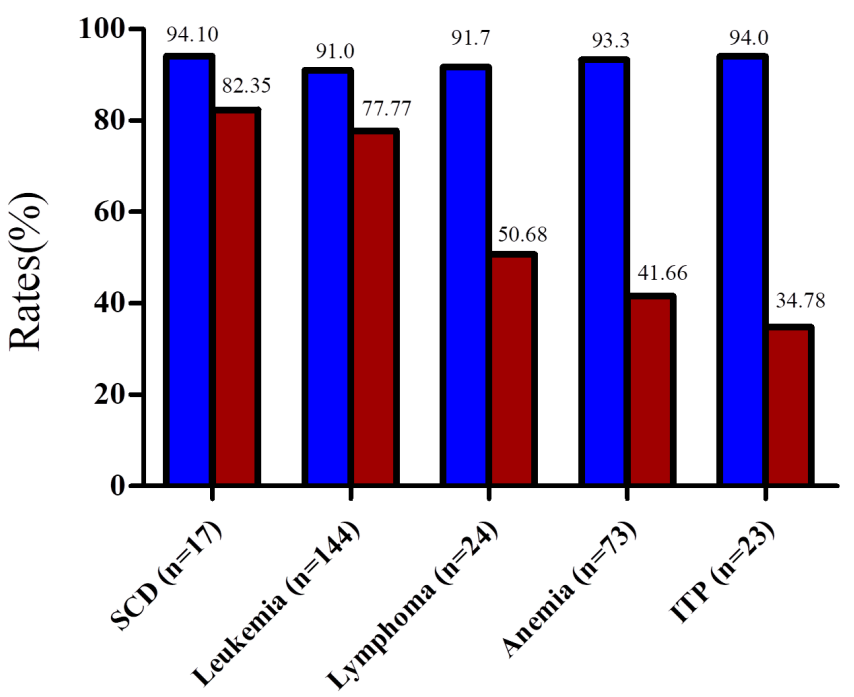

Figure 1

Rates of CMV prevalence and blood transfusions among patients with hematological diseases. All patients subject of this analysis were submitted to more than one blood transfusion during a one-year period. ITP: Immune thrombocytopenic purpura 
Figure 2

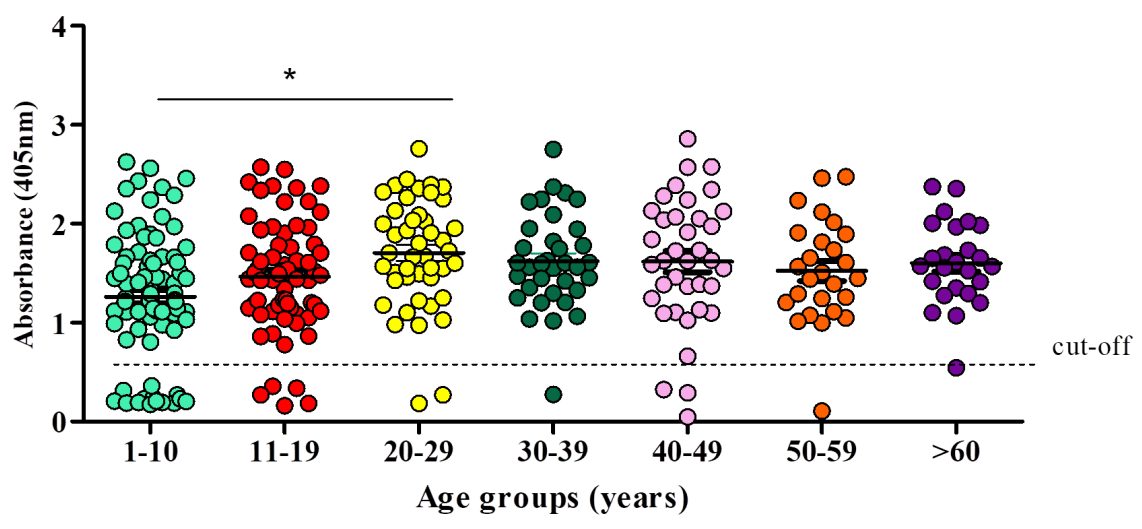

Figure 2

Serum levels of CMV IgG Abs according to the age. ( $p=0.02$, One-way ANOVA and Student's t-test). 
Figure 3

(a)

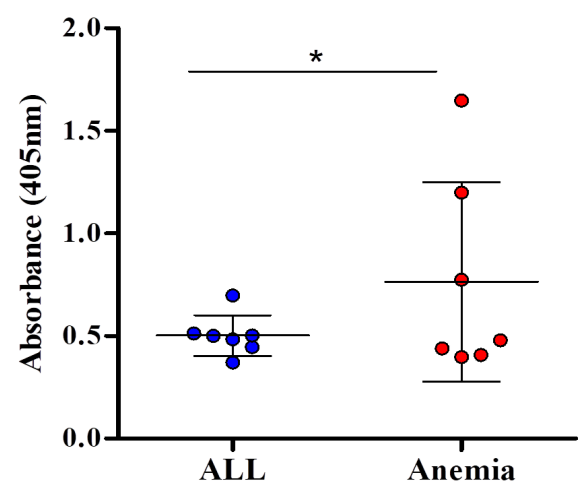

(b)

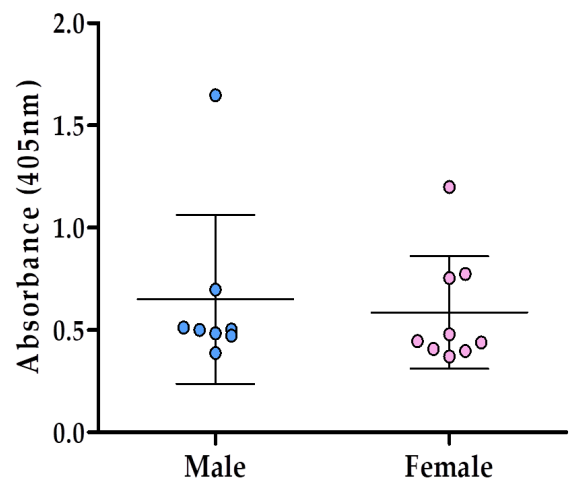

Figure 3

Serum levels of CMV IgM Abs. (a) difference of CMV IgM abs levels between patients with ALL and anemia; (b) Serum CMV IgM abs levels according to sex; * $p=0.001$ (F-test). 
Figure 4

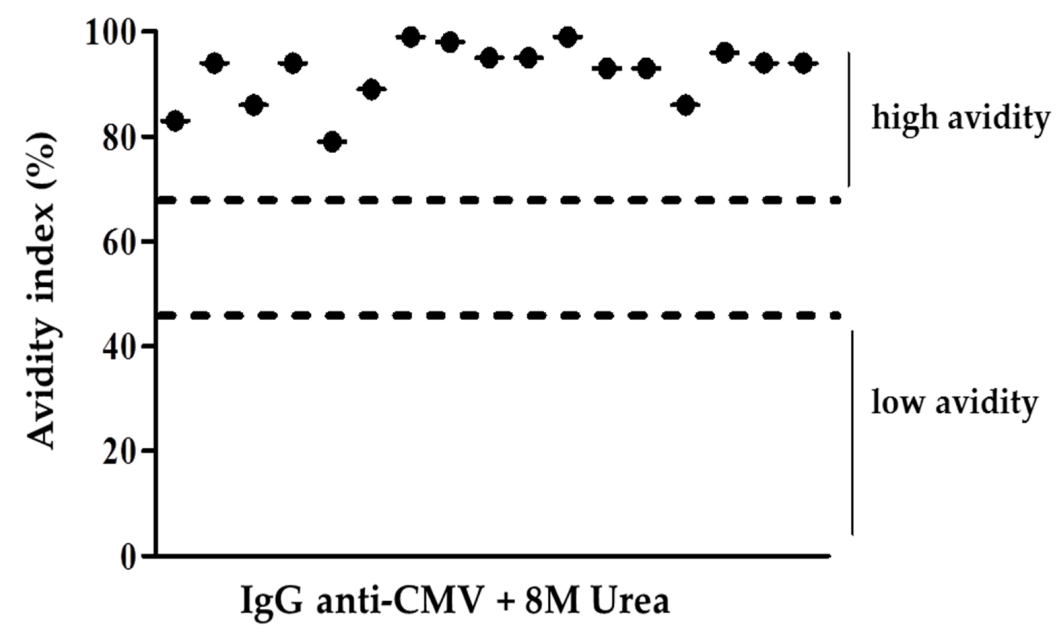

Figure 4

Avidity index values of IgG CMV levels of positive patients to IgM CMV. Low avidity represented by values $<45 \%$ and high avidity represented by values $>65 \%$.

\section{Supplementary Files}


This is a list of supplementary files associated with this preprint. Click to download.

- figuresupplemmetary1.tif 